\title{
Functional Analysis of Narrative Texts in Elementary School Textbook "Fly with English"
}

\author{
Ambar Jati ${ }^{1 *}$ \& Manu Somphithak ${ }^{2}$ \\ ${ }^{1}$ Universitas Muhammadiyah Surakarta, Surakarta, Indonesia \\ ${ }^{2}$ Mahasarakham University, Kantharawichai, Thailand \\ *Email \& Phone: a320130096@student.ums.ac.id; +6287887726593
}

\begin{tabular}{|c|c|}
\hline \multicolumn{2}{|c|}{$\begin{array}{l}\text { Submitted: 2021-09-12 } \\
\text { Accepted: 2021-10-17 } \\
\text { Published: } 2021-12-20\end{array}$} \\
\hline Keywords: & Abstract \\
\hline $\begin{array}{l}\text { SFL } \\
\text { Ideational } \\
\text { meaning }\end{array}$ & $\begin{array}{l}\text { Background: This study is an analysis of narrative texts in Elementary School } \\
\text { textbook "Fly with English" based on lexico-grammar and context in the } \\
\text { framework of Systemic Functional Linguistics (SFL). This study is also expected } \\
\text { to give the pedagogical implication based on the context of teaching and } \\
\text { learning process }\end{array}$ \\
\hline Narrative text & $\begin{array}{l}\text { Method: This research uses descriptive qualitative type of study in investigating } \\
\text { the problem. In the technique of collecting data, the writer uses observation and }\end{array}$ \\
\hline $\begin{array}{l}\text { Process and } \\
\text { circumstance }\end{array}$ & $\begin{array}{l}\text { documentation. The writer finds } 95 \text { clauses in narrative text. In analyzing the } \\
\text { data, the writer uses lexico-grammar of SFL framework to answer the first } \\
\text { problem. Moreover, the writer refers to context of SFL framework to answer the } \\
\text { second problem, and the writer also uses context of teaching and learning to } \\
\text { answer the third problem. } \\
\text { Result: Based on the result, there are six types of processes in the narrative text, } \\
\text { those are: (1) material process (40\%), (2) mental process (23,1\%), (3) relational } \\
\text { process (20\%), (4) verbal and behavioral process (7,4\%), and (5) existential } \\
\text { process (2,1\%). The writer also finds fifteen types of the participants, namely } \\
\text { actor, goal, senser, phenomenon, sayer, verbiage, carrier, attribute, token, } \\
\text { value, receiver, client, recipient, behaver, and existent. Moreover, the writer } \\
\text { finds six types of circumstances, that are, location, matter, manner, } \\
\text { accompaniment, cause, and extent. } \\
\text { Implication: The pedagogical implication of studying Systemic Functional } \\
\text { Linguistics (SFL) in narrative text is to give the insight of the teacher about SFL } \\
\text { genre pedagogy in teaching and learning process. In functional grammar, } \\
\text { teacher can teach the language features in different ways, such as by } \\
\text { introducing the terms of processes, participants, and circumstances that } \\
\text { contain in the narrative text clauses. }\end{array}$ \\
\hline
\end{tabular}

() 2021. This work is licensed under a CC BY-SA 4.0 


\section{INTRODUCTION}

Grammar has evolved from time to time. There are two major kinds of grammars which have had a major influence in the entire of the world, that is, formal and functional grammar. Formal grammar is a descriptive approach which concerns on set-up in producing sentences correctly. In this grammar, it is claimed that a sentence is combined by element of phrase. It is more concerned on how the sentence itself is constructed rather than with the implications of individual words. Formal grammar covers the prescriptive approach to language that's normally taught in English-language schools from kinder to college. In this grammar, a sentence consists of subject and predicate. It can be concluded that formal grammars formulate the rules.

On the other hand, functional grammar or known as Systemic Functional Grammar (SFL) has been proposed originally by Halliday (Teich, 1999: 20). SFL focuses on how language constructs a meaning. It considers context and social network to determine the meaning. It attempts to explain language in actual use and to investigate the connection between text and context in social life. In SFL, there are three components of meaning. They are generalized as term "metafunction" which includes three language functions, namely ideational, interpersonal and textual (Halliday \& Matthiessen, 2014: 211).

In everyday life, we usually tell what is going on and the fact happened around us. To reveal the meaning on the fact of everyday life can be known as ideational meaning. The ideational meaning is the meaning based on the phenomena, experiences or realities. In representing a phenomenon, ideational meaning has customary structure which consists of process and participant. An expert argues that ideational meaning represents some kinds of processes, some phenomena, participants and other aspects which have a relation among them (Halliday, 2014: 212).

Ideational meaning is interesting to be conducted because it explores the potential of English clause for representing our experience of the world. Furthermore, the importance of ideational meaning in SFL has induced a number of researches to investigate it. The previous studies about ideational meaning have been done by many researchers, such as, a study of SFL by Kazemian, Behnam, Ghafoori (2013), Soemantri, Indrayani, Afrianto (2014) and Dwi's research (2010). Most of the researches above have examined the ideational meaning realized in songs, speeches, and poems. Therefore, the researcher takes narrative texts in Elementary School textbook "Fly with English" as the data source.

"Fly with English" is a textbook which is used by some Elementary Schools in Indonesia that consists of pupil's book and workbook. The textbook is written by Frances Treloar and Steve Thompson. It is published firstly in 2012 by Marshall Cavendish Education, Singapore. After more observation of that textbook, the writer finds variation of structures and interesting theme and rheme in representing some phenomena of narrative text. In common, to reveal a phenomenon, ideational meaning consists of processes, participants, and circumstances in orderly. But, in that book, the structure of narrative text is not continual, and the author of this book more concerns on language function or meaning, such as, sometimes a clause is initiated by adjuncts, processes and etcetera. That is why, the writer interests to investigate deeply the ideational meaning realized in this book.

The reason why the writer chooses narrative texts because it is a text which has social function to amuse or entertain and to deal with actual and vicarious experiences in different ways (Gerot and Wignell, 1994: 204). Narrative texts have some variations created by an author based on her/his experiences. So, it is more interesting to be studied. By choosing narrative texts as the data source, it will give more understanding for the teacher to choose the text which is relevant to pedagogy and suitable with the student's context. 
This research aims to (1) find out the types of processes, participants, and circumstances, (2) describe the ideational meaning, and (3) explain the pedagogical implication of the study of ideational meaning. Based on the researcher observation in libraries, the researcher finds some similar researches which have conducted in order to prove the originality of this research.

The first research was investigated by Dwi (2010) entitled Ideational Meaning and Thematic Analysis on Children's Songs in Barney "Dancing and Singing" Series. In analyzing this research, he uses Systemic Functional Grammar (SFL) introduced by Halliday (1985). The data consist of nine songs. Qualitative study is conducted in his research. Referential identity is used to analyze the data. The result of the study shows that this album consists of 115 clauses and the ideational meaning which is discovered in this serial song, such as friendship, desire, admiration, and etcetera. In the development of theme, the song's writer uses two patterns, namely re-itteration and zig-zag.

The second research, Nazhirin (2013) attempted the research entitled A Transitivity Analysis of Genres in the Tenth Grade Senior High School Textbook "Developing English Competencies" based on Halliday's theory of Systemic Functional Linguistics. This research is expected to give the knowledge of genre's register features which will enhance linguistic competence. He uses quantitative and qualitative techniques. Quantitative technique is used to provide the frequency of occurrences; meanwhile qualitative technique is applied to interpret each process. The data is collected from reading section in the textbook. Based on the result, there are six types of process found;

(1) material process was found 116 times, (2) relational process was found 56 times, (3) mental process was used 28 times, (4) verbal process occurred 28 times, (5) behavioral process was found 8 times and (6) existential process was found 7 times in the analysis. The factor of curriculum influences the result in quality; the curriculum conveys the information to a textbook concerning the categorization of vocabulary.

The third research was studied by Soemantri, Indrayani, Afrianto (2014) entitled Transitivity Analysis on Shakespeare's Sonnet. Descriptive analysis method is conducted in this research to elaborate the types of process appearing in transitivity analysis and to identify archaic word. There are three Shakespeare' sonnets, namely My Mistress' Eyes, That Time of Year and Let Me Not to the Marriage of True Mind as the data. Transitivity is used to analyze the data. The result of their study is found four process types from six types existing, and it is presented in percentage of table; they are material process (50\%), mental process $(26 \%)$, relational process $(22 \%)$ and existential process $(2 \%)$. The researcher also finds some archaic words; such as 'hath', 'mayst', 'see'st', 'fadeth', 'doth', 'perceivest', 'ere', 'thou', 'thy', and 'writ'.

The researcher obtains many references to gain more understanding in ideational meaning by functional analysis, because, there are some results which has discussed that almost all of their researches in previous studies above concern on Ideational meaning. Although, the three researches above have the same object with this research, that is the study of ideational meaning, this research has the differences. This research focuses on functional analysis of narrative text in Elementary School textbook "Fly with English" that covers types of processes and pedagogical implication.

Several theories of Systemic Functional Linguistics (SFL) also presented in order to give a clear understanding about the research, such as: notion of grammar, systemic functional grammar, metafunction, ideational meaning, transitivity system, types of process and participants, types of circumstance, notion of text, narrative text, about textbook "Fly with English", and context of teaching and learning. 
Notion of grammar will obtain different interpretation based on certain approach. Some experts have presented a functional approach to grammar. Lock, Graham (1996: xi) stated "Grammar is viewed as a resource for creating meaning in spoken and written discourse". It implies that grammar becomes the central of producing meaning in language which can be used in spoken and written form. Systemic Functional Grammar is theory of language which has introduced and enhanced by M.A.K. Halliday at the University of Sydney, Australia which language is a part of social semiotics. Gerrot and Wignell (1994: 6) stated "Functional grammars view language as a resource for making meaning". It means that those grammar more concerns on language in use.

Relating the focus of the study in Systemic Functional Linguistics (SFL), Lock (1996: 8) stated that SFL has three components of meaning called 'metafunction' which can be analyzed in grammatical structures, namely ideational meaning, interpersonal meaning and textual meaning. Those meaning has different functions and analysis. Gerot and Wignell (1994: 12) stated "Ideational meaning is meanings about phenomena- about things, about goings, and circumstances surrounding these happenings and doings". It can be realized through 'transitivity'. While, Lock, Graham (1996: 174) stated "Interpersonal meaning is some of the ways in which speakers and writers structure clauses in order to interact with one another". It can be realized through 'mood' and 'modality'. Thus, Gerot and Wignell (1994: 14) stated "Textual meanings express the relation of language to its environment, including the verbal environment and the non-verbal environment". It can be realized trough 'theme' and 'cohesion' patterns.

Ideational meaning as limitation of this study can be realized through transitivity analysis. Gerot \& Wignell (1994: 52) stated transitivity system has three categories of meaning to represent phenomena of the real world, namely participants, processes, and circumstances. The example of transitivity pattern is as follow:

Table 2.1 Transitivity System

\begin{tabular}{lll}
\hline $\begin{array}{l}\text { The youngster } \\
\text { Actor }\end{array}$ & Wiggled & his loose tooth \\
\hline
\end{tabular}

Source Gerot \& Wignell 1994: 56

To divide the types of processes, the writer refers to some experts. According to Halliday, there are six types of processes, that are, material, mental, verbal, relational, behavioral and existential. However, according to Gerrot and Wignell, there are seven types of processes. They are same with Halliday, but they have added one more process, that is, meteorological process.

Gerot and Wignell (1994: 52) revealed "Circumstances answer such questions as when, where, why, how, how many, and as what". It means that circumstance gives detail information about place, time, manner, etc in which its context will be easier to understand. There are many types of circumstances, according to Halliday \& Matthiessen (2014: 313314) circumstance differentiates into nine types, that are extent, location, manner, cause, contingency, accompaniment, role, matter, and angle.

Relating to narrative text as the data, Nazhirin (2013: 25) states that "narratives construct a pattern of events with a problematic and/or unexpected outcome that entertains and instructs the reader or listener." It can amuse the readers, because it contains many extraordinary events. It can give instruction, because it gives moral value, and the problem can be resolved. Narrative text usually is taught for English learner in Indonesia from beginning until advance. 


\section{RESEARCH METHOD}

The researcher uses qualitative type of study to investigate the problem. Qualitative research is appropriate to be conducted in humanities social science, because the main objective of qualitative study is to understand the phenomenon, fact, reality and event which are experienced by human. Every human has different phenomena. There are many things in human life that can be understood only and cannot be calculated in statistics (Raco, 2010: xviii).

This study uses observation and documentation in the technique of collecting data. The writer finds 95 clauses in narrative text. In analyzing the data, the writer uses lexicogrammar of SFL framework to answer the first research question. Moreover, the writer refers to context of SFL framework to answer the second research question, and the writer also uses context of teaching and learning to answer the third research question. To get dependability of the data, the writer employs triangulation in this study.

\section{FINDINGS AND DISCUSSION}

After analyzing the text by using lexicogrammar in the framework of SFL, namely transitivity, the writer finds ninety five clauses in this research. The distribution table of processes, participants, and circumstances that characterize this text can be seen as follow:

Table 1: Process Types of Narrative Text in Textbook "Fly with English"

\begin{tabular}{lll}
\hline Process Types & $\begin{array}{l}\text { Frequency of } \\
\text { Occurrence }\end{array}$ & Percentage (\%) \\
\hline Material & 38 & 40 \\
Mental & 22 & 23,1 \\
Relational & 19 & 20 \\
Verbal & 7 & 7,4 \\
Behavioral & 7 & 7,4 \\
Existential & 2 & 2,1 \\
Total & 95 & 100 \\
\hline
\end{tabular}

Table 2: Circumstances of Narrative Text in Textbook "Fly with English"

\begin{tabular}{lll}
\hline Circumstance & $\begin{array}{l}\text { Frequency of } \\
\text { Occurrence }\end{array}$ & Percentage (\%) \\
\hline Location & 24 & 46,1 \\
Matter & 1 & 2 \\
Manner & 14 & 26,9 \\
Accompaniment & 4 & 7,7 \\
Extent & 8 & 15,3 \\
Cause & 1 & 2 \\
Total & 52 & 100 \\
\hline
\end{tabular}


Table 3: Participants of Narrative Text in Textbook "Fly with English"

\begin{tabular}{l|ll}
\hline Participants & $\begin{array}{l}\text { Frequency of } \\
\text { Occurrence }\end{array}$ & Percentage (\%) \\
\hline Actor & 27 & 19,3 \\
Goal & 14 & 10 \\
Senser & 21 & 15 \\
Phenomenon & 15 & 10,7 \\
Sayer & 7 & 5 \\
Verbiage & 2 & 1,4 \\
Carrier & 7 & 5 \\
Attribute & 7 & 5 \\
Token & 11 & 7,9 \\
Value & 11 & 7,9 \\
Receiver & 4 & 2,8 \\
Client & 5 & 3,6 \\
Recipient & 2 & 1,4 \\
Behaver & 5 & 3,6 \\
Existent & 2 & 1,4 \\
Total & 140 & 100 \\
\hline
\end{tabular}

Types of Processes and Participants

Types of processes and participants found in this narrative text based on the analysis will be discussed deeply in this section. Those are as follow: Material Process. Material process is processes of doing something. The material process can be an activity physically. The writer finds $40 \%$ of materials process. The participants in this process mainly concern on actor and goal. Based on the table in findings, actor appears twenty seven times, and goal appears thirteen times. The other participants which is found are receiver and client, that are, four and five times in order. The participants of the material process are $35,7 \%$. The participant of range cannot be found in this analysis. It indicates that the author often employs the process of happening or doing in order to reveal the idea or experience that are appropriate with the learner's level. The writer can prove it by showing the analysis. The material processes that the writer found in this text are as follow: 
Table 4.5 The example the material process found in the text

Datum 12

\begin{tabular}{|c|c|c|c|}
\hline It & Was & trying to eat & the plastic bag \\
\hline Subject & Finite & Predicator & Complement \\
\hline Mood & & Residu & \\
\hline $\begin{array}{l}\text { Participant: } \\
\text { Actor }\end{array}$ & \multicolumn{2}{|c|}{ Process: Material } & Participant: Goal \\
\hline
\end{tabular}

Datum 14

\begin{tabular}{|c|c|c|c|}
\hline & ried to cat & & \\
\hline Subject & Finite & Predicator & Complement \\
\hline \multicolumn{2}{|c|}{ Mood } & \multicolumn{2}{|c|}{ Residu } \\
\hline $\begin{array}{l}\text { Participant: } \\
\text { Actor }\end{array}$ & Process: I & & Participant: Goa \\
\hline
\end{tabular}

\section{Datum 36}

The octopus
\begin{tabular}{|l|l|l|l|}
\hline Subject & Finite & Predicator & Complement \\
\hline Mood & Residu \\
\hline Participant: Actor & Process: Material & Participant: Goal \\
\hline
\end{tabular}

The material process in the examples above is shown by the word eat, catch, and waved. All of the examples use actor and goal participants. In applying material process, the author of the text use the customary ordering, that are, initiated by actor, followed by material process, and continued by goal. The first example tells about activity that done by actor "it" , such as eat the plastic bag. Based on the full text, the word "it" refers to the turtle. The case is the turtle wants to eat the plastic bag, because people throw the rubbish in the sea.

In the second example tells about the activity done by the actor "he" in order to catch something. In this context, the word "he" refers to Bill as the main participants in this narrative text. Bill wants to catch the turtle that wants to eat plastic bag. The third example tells about an activity of waved done by an octopus. The story tells about an octopus that can do something like human. An octopus waves its arms in order to help Bill that falls in the sea.

\section{Types of Circumstances}

Types of circumstances characterized this narrative text based on the analysis will be discussed deeply in this section. Those are as follow: Circumstance of Location. Circumstance of location is the dominant circumstance in this analysis. It appears $46,1 \%$. Circumstance of location consists of two parts, namely time and place. The circumstance of time appears six times, whereas circumstance of place appears eighteen times. The author who employs many circumstances of location will give clear setting of the narrative text, so the reader will understand the plot of story. The analysis will be presented in the table below to support this description. 
Table 4.11 The example the circumstance of location found in the text

\section{Datum 46}

\begin{tabular}{|l|l|l|l|l|} 
Bill & Was & Looking & in the water & for some plastic bags \\
\hline Subject & Finite & Predicator & Adjunct & Complement \\
\hline Mood & Residu & $\begin{array}{l}\text { Circumstance } \\
\text { of Place }\end{array}$ & $\begin{array}{l}\text { Participant: } \\
\text { Phenomenon }\end{array}$ \\
\hline $\begin{array}{l}\text { Participant: } \\
\text { Senser }\end{array}$ & Process: Mental &
\end{tabular}

\section{Datum 03}

\begin{tabular}{|l|l|l|l|}
\hline \multicolumn{2}{|l|}{ hoped to find } & Some & that day \\
\hline Finite & Predicator & Complement & Adjunct \\
\hline Mood & Residu & $\begin{array}{l}\text { Participant: } \\
\text { Goal }\end{array}$ & Circumstance of Time \\
\hline Process: Material &
\end{tabular}

In the table above, circumstance of place is shown by the word "in the water", and circumstance of time is shown by the word "that day". In the first example, the author gives the circumstance of place in order to give supporting information of the clause. In this case, the main character, Bill, wants to look some plastics by giving more identification by adding the word "in the water". All the readers will know that the rubbish of plastic is in the water. In the second example, the author gives the circumstance of time in order to show that the time is definite. In this case, Bill hopes to find some sea animals that he has learned in the school when he arrived at the beach. The word "that day" refers to the day which Bill is at the beach.

Relating to the pedagogical implication, English teachers can take the implication of this study, especially when genre-based approach to language teaching is adopted in functional grammar. The implication of studying Systemic Functional Linguistics (SFL) in narrative text is to give the insight of the teacher about SFL genre pedagogy in teaching and learning process. In functional grammar, teacher can teach the language features in different ways, such as by introducing the terms of processes, participants, and circumstances that contain in the narrative text clause.

\section{CONCLUSION}

Based on the result, there are six types of processes in the narrative text, those are: (1) material process $(40 \%),(2)$ mental process $(23,1 \%),(3)$ relational process $(20 \%),(4)$ verbal and behavioral process $(7,4 \%)$, and $(5)$ existential process $(2,1 \%)$. Material process is the dominant process. The writer also finds fifteen types of the participants, namely actor, goal, senser, phenomenon, sayer, verbiage, carrier, attribute, token, value, receiver, client, recipient, behaver, and existent. The most dominant participant is material's participants $(35,7 \%)$. It indicates that the author often employs the process of happening or doing in order to reveal the idea or experience that are appropriate with the learner's level. Moreover, the writer finds six types of circumstances, that are, location, matter, manner, accompaniment, cause, and extent. The result shows that the most dominant circumstance is circumstance of location $(46,1 \%)$. The author who employs many circumstances of location will give clear setting of the narrative text, so the reader will understand the plot of story. The pedagogical implication of studying Systemic Functional Linguistics (SFL) in narrative text is to give the insight of the teacher about SFL genre pedagogy in teaching and 
learning process. The researcher suggests for the next researcher to conduct the research in other functions or the whole functions in the framework of Systemic Functional Linguistic (SFL). Because, by employing three functions in analyzing text, the result will be more detail and comprehensive.

\section{REFERENCES}

Afrianto, et.al. (2014). Transitivity Analysis on Shakespeare's Sonnet. IOSR Journal of Humanities and Social Science (IOSR-JHSS), Vol. 19. Bandung: Universitas Padjajaran. https://www.iosriournals.org/iosr-jhss/papers/Vol19-issue1/Version1/K019117885.pdf

Arikunto, S. (2006). Prosedur Penelitian: Suatu pendekatan praktek. Jakarta: Rineka Cipta. Bloor, T., and Bloor, M. 2004. The Functional Analysis of English. London: Arnold.

Dwi, S.W. (2010). Ideational Meaningand Thematic Analysis on Children's Songs in Barney "Dancing and Singing" Series. Research Proposal. Semarang: Universitas Diponegoro. http://eprints.undip.ac.id/23414/2/IDEATIONAL MEANING AND THEMATIC ANAL YSIS ON CHILDREN.pdf

Emilia, E. (2014). Introducing Functional Grammar. Bandung: Dunia Pustaka Jaya.

Fauziati, E. (2014). Method of Teaching English as a Foreign Language (TEFL). Surakarta: Era Pustaka Utama.

Fauziati, E. (2016). Applied Linguistics: Principles of Foreign Language Teaching, Learning, andResearching. Surakarta: Era Pustaka Utama.

Fontaine, L. (2013). Analysing English Grammar: A Systemic Functional Introduction. New York: Cambridge University Press. https://doi.org/10.1017/CBO9781139026635

Gerrot, L. and Wignell, P. (1994). Making Sense of Functional Grammar. New South wales: Gerd Stabler.

Halliday, M.A.K. \& Matthiessen, C.M.I.M. (2014). Halliday's Introduction to Functional Grammar 4th ed. New York: Routledge. https://edisciplinas.usp.br/pluginfile.php/270705/mod folder/content/0/v.\%20Halli day $20 \% 20$ Matthiessen $\% 20$ \%20Hallidays\%20Introduction\%20to\%20Functional\%20Grammar.pdf?forcedownloa $\underline{d=1}$

Handayani, E. (2008). A Syntactic Analysis of Transitivity in the Song Lyrics "Still Not Getting any" of Simple Plan Album (Functional Grammar Approach). Research Paper. Surakarta: Universitas Muhammadiyah Surakarta.

Hidayat, Y. (2014). The Ideational Meaning Realised in the Written Discourse in Online Newspaper on Abdul Qodir Jaelani (AQJ). Thesis. Semarang: Universitas Negeri Semarang. https://journal.unnes.ac.id/sju/index.php/eej/article/view/6637

Kazemian, B. et.al. (2011). Ideational Grammatical Metaphor in Scientific Texts: A Hallidayan perspective. International Journal of Linguistics, Vol.5. Tabriz: Researchgate. https://papers.ssrn.com/sol3/papers.cfm?abstract id=2514368

Lock, G. (1996). Functional English Grammar: An Introduction for Second Language Teachers. Cambridge: Cambridge University Press.

Majid, A. (2011). Ideational Meaning of Procedure Text "How to Develop Telekinesis". Research Paper. Semarang: Universitas Diponegoro. https://ejournal3.undip.ac.id/index.php/engliterature/article/download/5721/5504

Nazhirin, M. K. (2013). A Transitivity Analysis of Genres in the Tenth Grade Senior High School Textbook "Developing English Competencies". Research Paper. Yogyakarta: Universitas Negeri Yogyakarta. 
Nufus, C. (2014). An Analysis of Transitivity Shift of Barack Obama's Translated Speeches. Research Paper. Bandung: Universitas Pendidikan Indonesia. http://repository.upi.edu/12142/

Raco, J. R. (2010). Metode Kualitatif (Jenis, Karakteristik, dan Keunggulannya), Jakarta: Gramedia Widiasarana Indonesia.

Salsabil, S. (2014). A Transitivity Analysis of English Texts in Bahasa Inggris When English Ringsthe Bell. Research Paper. Yogyakarta: Universitas Negeri Yogyakarta.

Seguin, R. (1989). The Elaboration of School Textbook. New York: Unesco.

Teich, E. (1999). Systemic Functional Grammar in Natural Language Generation. New York: Cassell.

Zuhud, D, et.al. (2014). Mental and Relational Process of Transitivity in Donne's and Blake's Poems: A Systemic Functional Linguistics Approach. International Journal of English and Education Vol.3. Bandung:

Universitas

Padjajaran.

http://ijee.org/yahoo site admin/assets/docs/1.83201153.pdf 